\title{
FZD2 wt Allele
}

National Cancer Institute

\section{Source}

National Cancer Institute. FZD2 wt Allele. NCI Thesaurus. Code C51445.

Human FZD2 wild-type allele is located in the vicinity of 17q21.1 and is approximately $2 \mathrm{~kb}$ in length. This allele, which encodes frizzled-2 protein, is involved in signal transduction involving Wnt target genes. 